\title{
Comparative analysis of transport services development in the capital cities moscow and colombo
}

\author{
Nina Danilina ${ }^{1 *}$, Champa Navaratne ${ }^{2}$, and H.A.C. Priyankara ${ }^{2}$ \\ ${ }^{1}$ Moscow State University of Civil Engineering, Jaroslavskoe sh., 26, korp. 1, Moscow, 129337, \\ Russia \\ ${ }^{2}$ University of Ruhuna, A2, Matara, 81000, Sri Lanka
}

\begin{abstract}
The study of urban transport service systems covers a wide range of issues connected with sustainability of urban areas, provision of high quality services and administrations in the cities and urban agglomerations that have transport problems related to population mobility. Each city develops its own particular concept of the transport service system development, based on a variety of external and internal factors. The article deals with transport development policies of two cities - Moscow and Colombo completely different in almost every aspect such as history, geopolitics etc, except one: both are the biggest capital cities of the corresponding states, Russian Federation and Sri Lanka. The task of the authors was to make theoretical comparative analysis of the most significant tendencies, processes and effects in the field of modern urban transport development of the above mentioned cities in order to identify their context specifics and factors that could determine the relationships between the development of the settlement system and the level of development of the transport system that allow to dialogue enrichment in strategic planning and practical decisions. The article presents the methods of analysis, statistical data, the results of a retrospective analysis of the relationship between the historical process, the modern management system and the level of development of urban transport service systems.
\end{abstract}

\section{Introduction}

The current trend in the development of cities around the world, regardless of where they are located, is the creation of a high-quality urban environment that meets the requirements of sustainable development.

This is also true for the creation of the transport system, which is the basis of the settlement system and largely determines the vector and speed of urban development.

There is an interesting research field related to the comparison of common and different features of the transport systems of countries that have followed completely different paths of development, without any reciprocal influence, due to the great distance from each other, different cultures, lifestyles, and specialization of the city.

\footnotetext{
* Corresponding author: DanilinaNV@mgsu.ru
} 
The common thing is that they are inhabited by people with the same basic needs in accomplishing everyday movements with labor, cultural and social goals. Of particular interest there are the capitals of states that are characterized by the greatest intensities of urban transport and pedestrian traffic, the fast pace of life and the complexity of the population mobility structure due to the concentration of different types of urban infrastructure.

Common to all cities will be the urban development background, which, according to the concept of sustainable development, proceeds from the following prerequisites:

- ensure public access to urban infrastructure with minimal difficulty to travel, which is determined by the time spent on the trip;

- minimize the anthropogenic impact of transport infrastructure and processes, as the main source of environmental pollution, on the environment;

- ensure efficient economic processes that are determined by the transport mobility of the population, as well as the conditions of transport services for key urban facilities.

The commonality of prerequisites arises from the commonality of problems: an imbalance of transport demand and supply, traffic congestion, poor quality of transport services for the population, etc.

In this context, as well as taking into account the novelty of emerging issues and the need to integrate development processes, it is important and useful to study the approaches and situational experience of different cities to solve common problems, since this experience is unique for each city because of its natural, climatic, historical cultural, social, political and many other reasons.

This article presents the results of an analytical review of the transport service systems of two world capitals that are located in different parts of the world and possess different historical experience of urban development.

Moscow is the capital of Russia, the largest country in the world by area, which has international borders with 16 sovereign states. The history of the city begins from the 12 th century, the model of urban development is similar to the model of the capitals of European countries influenced by Asian experience

Colombo is the commercial capital of Sri Lanka, which, since the 16th century, was colonized by Europeans and only since 1972 ceased to be the dominion of England and gained full independence. At present, the territory of the city of Colombo is actively developing on the basis of the urban infrastructure created during the colonization period, but under the strong influence of the specific characteristics of the country.

The aim of the article is to determine relationships between the development of the settlement system and the development of the transport systems.

\section{Materials and Methods}

The study was conducted on the basis of the factor analysis methods, which allows to systematically describe the object of study (the system of transport services) and to identify the variable factors responsible for the presence of relationships between the observed variables. In our case, it involves the following steps:

1. Description of the objects of study - the transport service system of Moscow and Colombo on a specific set of parameters;

2. Identify the factors that determine the current state of each transport service system;

3. Identification of common and variable factors that determine the development of transport service systems;

4. Formulation of general forecasts for the development of transport service systems of the cities. 
The structure of the study is presented in Fig. 1.

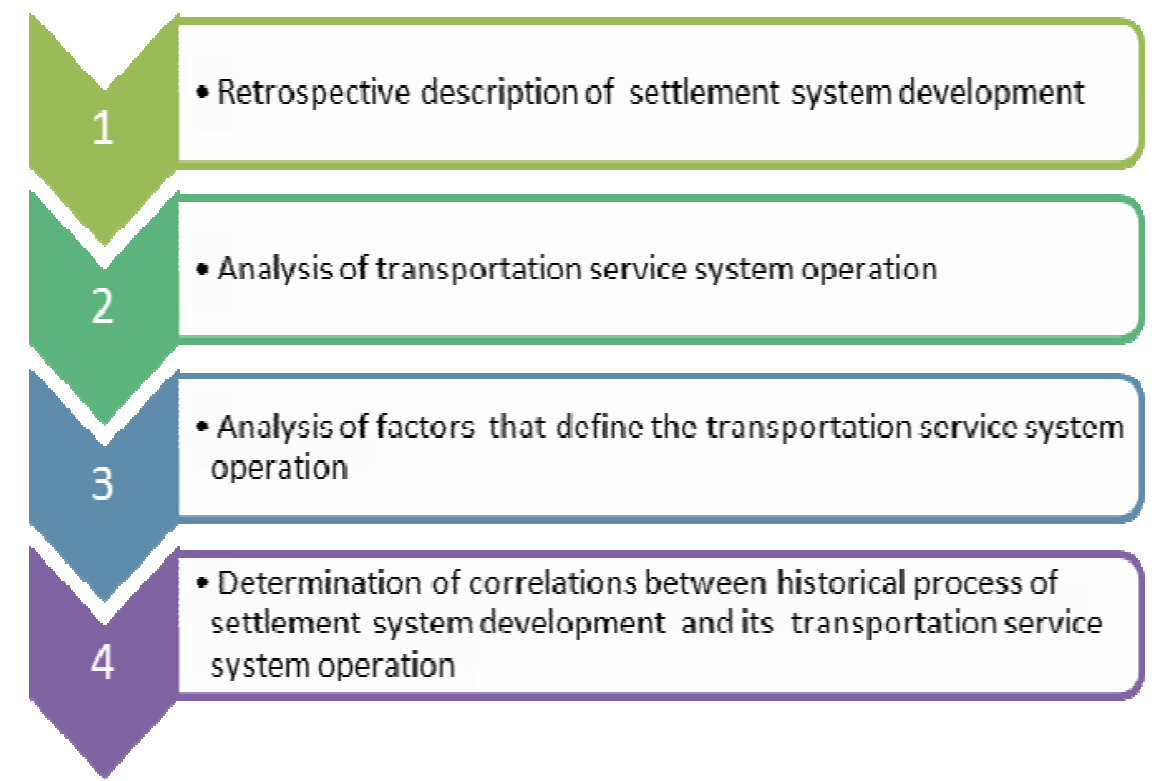

Fig. 1. Structure of the study of relationships between the historical process of development of the settlement system and the level of development of the transport system

\section{Implementation}

\subsection{Retrospective Description of the Development of the City Settlement System}

The natural harbor and the settlement of Colombo was already known to sea traders from the III-IV centuries, later, from the VIII century, it acquired the importance of a large port city, the sea trade in which was controlled by the Arabs. The next stage of active development of the city began in the XIV century with the arrival of Europeans in the country.In 1802 Colombo became the capital of the first British colony of Ceylon, then, in 1948, of the dominion capital of Ceylon, and since 1972 - of the democratic socialist republic of Sri Lanka. Despite the transfer of the legislative capital to the city of Sri Jayewardenepuru-Kotte (since it is situated in Greater Colombo agglomeration), Colombo remain the largest city of the country and is referred to as the capital of the country. The transport infrastructure of the city was developing in a natural way, meeting the interests of a growing city. A major contribution to the development of passenger transport was made by the British, who built the railway net work, which currently represents the frame of passenger traffic in the Greater Colombo agglomeration. Today, urban areas are under active development, including the extensive development of transport infrastructure with a focus on sustainable development of territories, improving the polycentric settlement system and quality of transport services. Fig.2 shows the urban development plan for the city's territories, which implies the formation of two urban activity centers: the central business district that adjoins the port area on a sea coast and the historical administrative center away from the sea, and contemporaneously, a system of high-speed highways that will ensure connectivity between the districts of the city. 


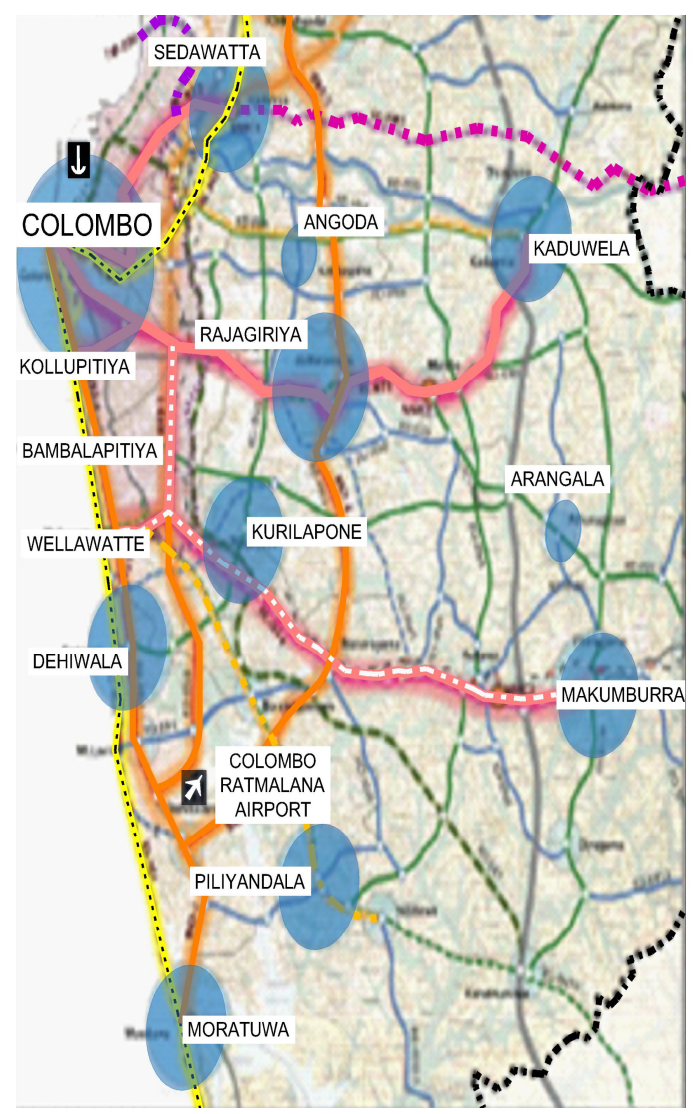

\section{URBAN CENTERS}

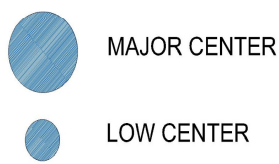

PUBLIC TRANSPORT NETWORK
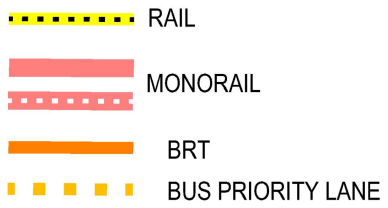

I I I I I RIVER LANE

ROAD NETWORK

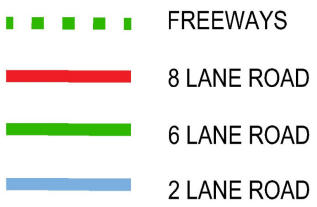

EXTERNAL TRANSPORT

$\begin{array}{ll}\downarrow & \text { PORT } \\ \lambda & \text { AIRPORT }\end{array}$

Fig. 2. Colombo public transport development plan. Source: Ministry of Transport- Urban Transport Development Project Final report, Urban Transport Master Plan 2035 (p.29)

The first reference to Moscow dates from 1147, since this time the city experiences dynamic development, absorbing the best European and Asian knowledge for the improvement of the transportation system.

The city has a pronounced ring-radial streetpattern, which shapes the development orientation of transport and communication framework.

The spatial development of the city is determined by the General Plan of Moscow until 2025.

At present, transport policy of Moscow, as well as Colombo, is oriented primarily towards sustainable development of the territories of the city's transport system.

The General Plan defines the direction for improving intermodal passenger transport system based on the priority development of high-speed off-street passenger transport (Fig. 3). The transport and communication framework is represented by the Moscow MetroSystem, Monorail and Moscow Central Circle.

The basis of development is the system of transport hubs, the number of which in the territory of Moscow exceeds 300 units. They are the places of the passengers exchange between different vehicles and transport modes: passenger and personal, as well as the centers of transit oriented development where residential, administrative, business, cultural, recreational functions of the city are actively developing. 


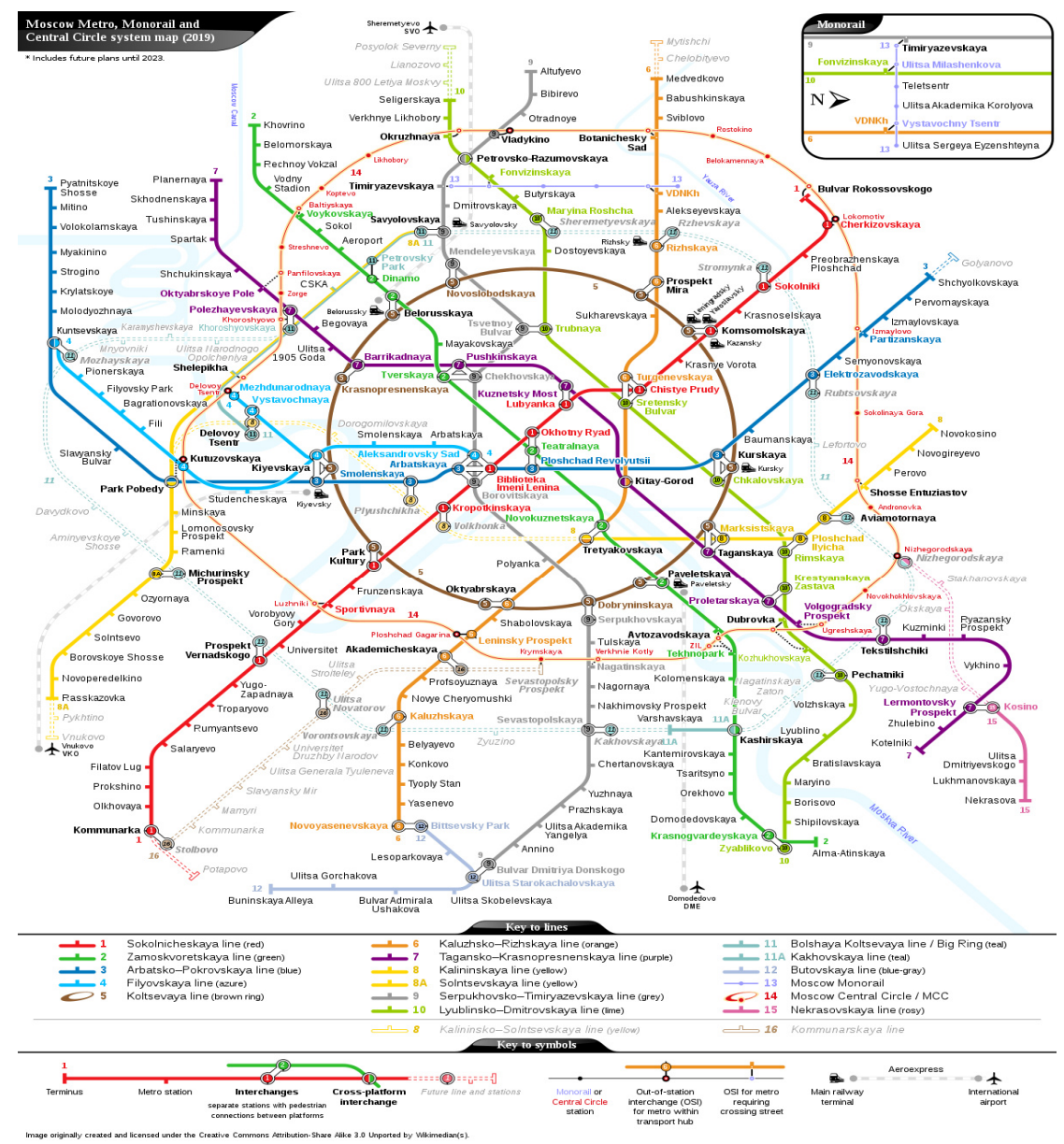

Fig. 3. Moscow public transport development plan. Source: Official site of Moscow authorities www.stroi.mos.ru

\subsection{Analysis of the City Transport Service System}

Table 1 provides a description of the transport service systems of Moscow and Colombo on the main parameters characterizing:

1. The nature of traffic flows generation directedto the main focuses of population during the morning rush hours;

2. The numerical indicators of the settlement system, such as the city area, the density of population;

3. Numerical indicators of the work of the transport system: the density of the road network, vehicles to population ratio as number of vehicles per 1000 citizens, the average speed of traffic in the morning rush hour.

4. The descriptive characteristics of the urban transport system: the composition of the urban traffic flow and the composition of the passenger transport system. 


\subsection{Analysis of Factors that Determine the Operation of the Transport Service System}

Analysis of the factors determining the operation of the transport service system is carried out for each of the aspects of sustainable development:

1. Social aspect of the transport system performing consists mainly in function of providing the population with access to the focus of attention and the quality of services;

2. The economic aspect evaluates the efficiency level of transport system performance, including investment attractiveness, issues of work management, coordination of private and public carriers, etc.

3. The environmental aspect of transport system performance determines the environmental quality factors.

Table 2 presents the results of a more detailed analysis of the current state of the Colombo transport service system using the SWOT - analysis method, which indicates the main factors that determine the problems and prospects for its development.

Table 3 presents the results of the SWOT - analysis, which indicates the main factors determining the problems and prospects for the development of the Moscow transport service system.

A comparison of the results suggests a number of problems for Colombo. It should be noted that Moscow faced the same problems as Colombo 10-15 years ago. A qualitative leap in the development of the city's transport system occurred in the years 2000, thanks to a stage of economic growth in the country.

For Colombo, the situation is different: according to the Sunday Times newspaper, the forecast in the development of the transport service system is negative, for example, the average speed is expected to drop to $15 \mathrm{~km} / \mathrm{h}$ by 2031, Further, it is mentioned that city authorities understand that fundamental changes are required in the existing transport policy of the city in order to prevent negative consequences. There is a plan for the development of the Colombo transport system, which includes the development of the structure of highways, the construction of a line of light rail Colombo - Malabe, the development of bus routes. But still, a big problem is the small degree of elaboration of special documents defining the integral transport policy of the country and its capital. However, the analysis allows us to identify common for two cities sustainable transport policy trends aimed at:

- priority development of passenger transport;

- development of intermodal transportation through the formation of a system of transport hubs;

- organization of access control to the road network;

- increasing the coherence of the territory of the city and suburbs within the borders of the developing agglomeration;

- improving the quality of services for the population;

- development of urban parking spaces;

- the intensification of the construction and modernization of existing new routes of street and off-street passenger transport;

- management of the transport behavior of car owners;

- development of urban planning documentation and methods of urban planning management. 
Table 1. Transport systems comparison

\begin{tabular}{|c|c|c|}
\hline Moscow city & Param. / Char. & Colombo city \\
\hline $2561,5 \mathrm{~km}^{2}$ & City area & $37.32 \mathrm{~km}^{2}$ \\
\hline 12630289 & Population & 752993 \\
\hline 15512000 & Agglomeration & 5648000 people \\
\hline $\begin{array}{l}10500 \mathrm{ple} . / \mathrm{km}^{2} \\
\text { (without New Moscow district) }\end{array}$ & Density of population & 20177 ple. $/ \mathrm{km}^{2}$ \\
\hline 350 & $\begin{array}{l}\text { Level of auto } \\
\text { mobilization, number of } \\
\text { car per } 1000 \text { citizens }\end{array}$ & $\begin{array}{c}130 \text { (out of which } 66 \% \text { would be } \\
\text { two-wheelers and three-wheelers, } \\
\text { four-wheelers, small and large, } \\
\text { making up } 45 \text { vehicles per } 1,000 \\
\text { people) }\end{array}$ \\
\hline $4,2 \mathrm{~km} / \mathrm{km}^{2}$ & Density of road network & $1.96 \mathrm{~km} / \mathrm{km}^{2}$ \\
\hline $30 / 70$ & $\begin{array}{l}\text { Ratio between cars / } \\
\text { public transport use }\end{array}$ & $55 / 45$ \\
\hline $\begin{array}{l}\text { Bus, trolley, tram, metropolitan, } \\
\text { light rail, commuter rail }\end{array}$ & Public transport modes & $\begin{array}{l}\text { Route and non-route buses, } \\
\text { commuter rail }\end{array}$ \\
\hline 56 & $\begin{array}{c}\text { Average traffic } \\
\text { velocity,Km/hour }\end{array}$ & 26 \\
\hline $\begin{array}{l}\text { Land modes: bus, trolley, tram } \\
\text { Off-road modes: Metro, Light rail, } \\
\text { monorail, commuter rail }\end{array}$ & $\begin{array}{l}\text { Composition of public } \\
\text { transport modes }\end{array}$ & $\begin{array}{c}\text { Land mode: bus (government and } \\
\text { private owned) } \\
\text { Commuter Rail }\end{array}$ \\
\hline $\begin{array}{l}\text { Windividual transport } \\
\begin{array}{l}\text { w freight transport } \\
\text { on-land public } \\
\text { transport }\end{array}\end{array}$ & $\begin{array}{l}\text { Composition of } \\
\text { transport flow }\end{array}$ & $\begin{array}{l}\text { individual cars } \\
\text { freight } \\
\text { transport } \\
\text { on-land public } \\
\text { transport }\end{array}$ \\
\hline
\end{tabular}


Table 2. SWOT Analysis for Colombo city

\begin{tabular}{|c|c|}
\hline & iesses \\
\hline $\begin{array}{l}\text { - Historically road } \\
\text { maintenance funding has been } \\
\text { from budgetary allocations } \\
\text { - Intervention for Managing } \\
\text { Motorization in Metropolitan } \\
\text { Areas } \\
\text { - Program for Promotion of } \\
\text { Public Transport } \\
\text { - Introduction of a monorail } \\
\text { system } \\
\text { - Modernization of the } \\
\text { existing railway system } \\
\text { - Construction of an airport } \\
\text { connection line } \\
\text { - Development of access } \\
\text { roads to railway stations and } \\
\text { the proposed transit systems } \\
\text { - Introduction of bus rapid } \\
\text { transit (BRT) } \\
\text { - Road development to } \\
\text { introduce BRT } \\
\text { - Regulatory scheme for } \\
\text { road-based public transport } \\
\text { modes }\end{array}$ & $\begin{array}{l}\text { - Lack of effective transport demand management or transport } \\
\text { supply management strategy and deteriorating public transport } \\
\text { services, no visionary political leadership to develop public transport } \\
\text { to deliver satisfactory services and achieve a position of acceptance } \\
\text { in society. } \\
\text { - Undisciplined behavior of road users including drivers, riders, } \\
\text { passengers and pedestrians. } \\
\text { - Lack of institutional capacity and coordination } \\
\text { - Inadequate parking spaces in urban areas } \\
\text { - Problems of the railway network: insufficient linkage of the } \\
\text { network, lack of feeder services, insufficient integration among } \\
\text { public transport, lack of railway access to the international airports, } \\
\text { slow operational speed of rolling stock, insufficient line capacity, } \\
\text { insufficient expenditure for maintenance } \\
\text { - problems in bus transport and other road based public transport: } \\
\text { low bus operation speed and service level of bus operations, lack of } \\
\text { integration with railways other bus terminals, difficult coordination } \\
\text { between public and private bus operators, market driven regulatory } \\
\text { scheme of road based public transport modes } \\
\text { - Problems on road network; insufficient road network, lack of } \\
\text { pedestrian space, lack of a robust road network master plan for the } \\
\text { Colombo metropolitan region, lack of engineering design standards } \\
\text { for urban roads, low accessibility of the existing expressway } \\
\text { network } \\
\text { - Problems on traffic control and traffic management/ }\end{array}$ \\
\hline
\end{tabular}

\section{Opportunities}

\section{Treats}

- Public Transport being viewed as a socio-welfare service

- Intervention for Improving Inter-Provincial Connectivity:

- Established Transport Studies and Planning Centre (TSPC) (that was set up with World Bank funding)

- Political attention and government involvement of this sector

- Promoting Non-Motorised Transport

- Potential to develop internal water ways for transportation purposes.
- Decreasing of average speed in Colombo city area

- The numbers of road accidents and fatalities has steadily increased

- Private sector participation is limited and restricted in railway operations.

- Rapid increase in vehicle ownership and use and the increase in demand for road space requires

- Vehicle and traffic growth especially in urban areas will be constrained by space availability to provide the required road space

- No particular agency responsible for managing issues arising from rapid motorization and there is a gap of a mechanism for determining funding between the different modes of transport.

- Transport system is centered on Colombo city center and is road dominated without efficient linkages to other modes and nodes for a holistic multi modal transport operation and for assisting laggingregions to develop rapidly. 
Table 3. SWOT Analysis for Moscow city

\begin{tabular}{|c|c|}
\hline Strengths & Weaknesses \\
\hline $\begin{array}{l}\text { - Support and financing of the transport } \\
\text { system development by the city } \\
\text { authorities. } \\
\text { - Existing well developed system of public } \\
\text { transport } \\
\text { - Approved program transport policy and } \\
\text { infrastructure development plans. } \\
\text { - Modernization of the existing on-land } \\
\text { public transport and railway systems and } \\
\text { development of their intermodal } \\
\text { connection. } \\
\text { - Development of access roads to railway } \\
\text { stations and the proposed transit systems } \\
\text { - Regulatory scheme for road-based public } \\
\text { transport modes. }\end{array}$ & $\begin{array}{l}\text { - Unbalance between transport demand and transport } \\
\text { supply management strategy, } \\
\text { - Insufficient involvement of the population in } \\
\text { transport planning processes } \\
\text { - Undisciplined behavior of road users including } \\
\text { drivers, riders, passengers and pedestrians. } \\
\text { - Problems of the railway network overloaded } \\
\text { especially in peak hours, not high speeds, middle } \\
\text { quality of vehicles. } \\
\text { - Problems of on-land road public transport: low bus } \\
\text { operation speed and service level of bus operations, } \\
\text { difficult coordination between public and private } \\
\text { bus operators. } \\
\text { - Problems of overloaded road network, lack of } \\
\text { pedestrian space, lack of its density } \\
\text { - Problems on traffic control and traffic } \\
\text { management. }\end{array}$ \\
\hline Opportunities & Treats \\
\hline $\begin{array}{l}\text { - Public Transport being viewed as a } \\
\text { socio-welfare service } \\
\text { - Political attention and government } \\
\text { involvement of this sector } \\
\text { - Promoting non-motorised Transport } \\
\text { - Potential to develop alternative way of } \\
\text { intermodal connection between different } \\
\text { modes of transport. } \\
\text { - Implementation of environmentally } \\
\text { friendly vehicles } \\
\text { - Development of transport modeling } \\
\text { technologies for smart city. }\end{array}$ & $\begin{array}{l}\text { - Insufficient involvement of educational and } \\
\text { scientific potential in practical transport planning } \\
\text { - Private sector participation is limited } \\
\text { - Rapid process of Moscow agglomeration territory } \\
\text { urbanization } \\
\text { - Lack of funding from the side of private sector } \\
\text { - Transport system is centered on Moscow city } \\
\text { center }\end{array}$ \\
\hline
\end{tabular}

\subsection{Determination of Relationships between the Historical Process of Development of the Settlement and Transport Systems}

Searching the reasons why there are differences between cities in the level of development of the transport service system, has generated the analytical work in order to determine the relationships between the development of the settlement system and the level of development of the transport system. The results are presented in table 4 . 
Table 4. The system of factors determining the level of development of the transport system of Moscow and Colombo

\begin{tabular}{lll}
\hline Factors & Common & Different \\
\hline $\begin{array}{l}\text { Town } \\
\text { planning }\end{array}$ & $\begin{array}{l}\text { Centric settlement system and } \\
\text { centripetal traffic flows }\end{array}$ & $\begin{array}{l}\text { Level of development of rural / urban } \\
\text { settlements in the suburbs }\end{array}$ \\
& $\begin{array}{l}\text { High level of urbanization } \\
\text { High density of the population }\end{array}$ & $\begin{array}{l}\text { Territory size and distanced } \\
\text { Types of urban planning regulation }\end{array}$ \\
\hline \multirow{2}{*}{ Economic } & Belonging to the world economic space & $\begin{array}{l}\text { Economic specialization and Gross } \\
\text { Domestic Product }\end{array}$ \\
& Organization of work of private and state \\
\hline Political & Participation in world politics & Geopolitical position: the world political \\
\hline \multirow{2}{*}{ Social } & Population stratification & $\begin{array}{l}\text { Cultural and historical background of } \\
\text { develonment }\end{array}$ \\
& Social service system development & Standards of living \\
& Intensive mobility of the population & Quality of transportation services \\
\hline \multirow{2}{*}{ Ecological } & Global ecological problems & Geographical position \\
& The priority for sustainable & Climate \\
\hline
\end{tabular}

In general, the comparative analysis demonstrates that Moscow has already an established transport policy, on the basis of which positive forecasts are being made for the development of the transport service system: an increase in the share of passenger transport users, an increase in the average speed of traffic, the development of the quality of intermodal travels, etc; while Colombo is still in the process of creation of the paths in transport system development: there has been reached a clear understanding of what to do and a program oriented at sustainable urban development, so the next step should be the implementation of the developed program and on this way Colombo can take into consideration both the Moscow experiences, both positive and negative.

\section{References}

1. A.S. Kumarage, Sri Lanka Transport sector policy note - final report, http://open_jicareport.jica.go.jp/pdf/12176665.pdf.

2. Department of National Planning, Ministry of National Policies and Economic Affairs of Sri Lanka. Investment program 2017 2020, http://www.mnpea.gov.lk/web/images/PIP_English/EnglishPIP-83-114.pdf.

3. G. Pilapitiya, Remedies for traffic congestion. The Sunday Times Sri Lanka, http://www.sundaytimes.lk/161120/business-times/remedies-for-traffic-congestion217284.html.

4. Indi.ca Colombo vehicle statistics 2015, https://indi.ca/2015/10/colombo-vehiclestatistics-2015/. 
5. Ministry of Megapolis and Western development, https://www.scribd.com/document/365419966/Megapolis-Transport-Masterplan-final.

6. Ministry of Transport (2014), Urban transport system development project-Final Report, http://open_jicareport.jica.go.jp/pdf/12176665.pdf.

7. Colombo Population 2019 (Demographics, Maps, Graphs), http://worldpopulationreview.com/world-cities/colombo-population/.

8. Moscow Mayor official website, https://www.mos.ru/dt/.

9. N. Danilina, International Conference on Sustainable Cities, Web of Conferences, E3S, 02001 (2016). DOI: 10.1051/e3sconf/20160602001

10. D. Vlasov, N.Danilina, A. Shagimuratova, Advances in Intelligent Systems and Computing. 692, 299-309 (2018). DOI: 10.1007/978-3-319-70987-1_32 